\title{
Juvenile fish use of the shallow zone of beaches of the Cananéia-Iguape coastal system, southeastern Brazil
}

\author{
Jana Menegassi del Favero*, June Ferraz Dias
}

\author{
Instituto Oceanográfico - Universidade de São Paulo \\ (Praça do Oceanográfico, 191, 05508-120, São Paulo - SP, Brasil) \\ *Corresponding author: delfaverojana@gmail.com
}

\begin{abstract}
The purpose of the present study is to describe the juvenile fish use of the shallow zone of beaches of the Cananéia-Iguape coastal system, São Paulo, Brazil, analyzing its occurrence period and the patterns of utilization for the most abundant species. Using a beach seine monthly for one year, we sampled 13861 individuals, of 57 species and 24 families. The fish species used the study area for different proposes: Atherinella brasiliensis was sampled in all phases of gonadal development and considered as resident, juveniles of Trachinotus goodei used the beaches for growth and juveniles of Mugil curema and Mugil liza used the beaches as a route from the ocean to the estuary. Our results showed the importance of the sandy beaches for juvenile fish, especially in spring and summer when most juveniles occur and recruit. Unfortunately, this is the period of the most intense tourist activity. As many of the species studied are commercially important, this study highlighted the necessity of coastal habitat preservation for better fishery management.
\end{abstract}

Descriptors: Ichthyofauna, Seasonality, Recruitment, Surf zone.

\section{Resumo}

O objetivo do presente estudo é descrever o uso por peixes juvenis da zona rasa de praias arenosas do sistema costeiro Cananéia-Iguape, São Paulo, Brasil, analisando o período de ocorrência e o padrão de utilização das espécies mais abundantes na área. Utilizando uma rede de arrasto de praia (picaré) mensalmente ao longo de um ano, foram amostrados 13861 indivíduos, pertencentes a 57 espécies e 24 famílias. As espécies analisadas utilizaram a área estudada com diferentes finalidades: Atherinella brasiliensis foi amostrada em todas as fases do desenvolvimento gonadal e, portanto, considerada como residente, juvenis de Trachinotus goodei utilizaram as praias para o crescimento, enquanto os juvenis de Mugil curema e Mugil liza como rota de migração do oceano para o estuário. Nossos resultados mostraram a importância das praias arenosas para peixes juvenis, principalmente na primavera e no verão, quando a maioria dos juvenis recruta na área, e coincide com o período de maior impacto pelos turistas. Como muitas espécies analisadas são comercialmente importantes, ressalta-se ainda a importância de preservação desses habitats costeiros para um melhor manejo pesqueiro.

Descritores: Ictiofauna, Sazonalidade, Recrutamento, Zona de arrebentação. 


\section{INTRODUCTION}

Environmental conditions have a direct effect on recruitment and, consequently, on population size. Habitats with inadequate physical, chemical or biological environmental conditions for fish can cause a reduction in fecundity, in individual growth rate and an increase in mortality (WENER, 2002). The recognition and preservation of habitats that favor the survival of fish is clearly important to maintain their stocks. However, fish may experience different habitats, from spawning to maturity (Triangle Migration Hypothesis - HARDEN JONES, 1968). Nevertheless, it is in the initial phase of the life cycle that environmental conditions may exert a greater influence on fish survival, because, among many other factors, it is at this stage that the organisms are more vulnerable to environmental changes and have limited swimming ability to move, by themselves, to a more suitable habitat (HJORT, 1914).

The process of adding new individuals to a specific stage of the species' life cycle is known as recruitment (JENNINGS et al., 2001). Thus, the survival of juveniles and larvae is related to success in the recruitment of individuals to the adult stock, which in turn is related to the population size. Knowledge of possible environmental factors and human activities that affect fish survival, especially in the initial stages of development, is important for fisheries management, coastal management and species conservation.

The surf zone of sandy beaches is considered an important growth and feeding area for many fish species (MCLACHLAN et al., 1981). Juvenile fish recruit in the surf zone because this area provides rich food resources such as components of zooplankton and benthic macrofauna and protection against predators provided by the shallowness, turbidity and turbulence of these areas (e.g. LASIAK, 1981; CLARK et al., 1996; PESSANHA; ARAÚJO, 2003; VASCONCELLOS et al., 2007). Furthermore, beaches located adjacent to estuaries, as are the beaches that we studied, are considered migration routes of many larvae and juvenile fish, which spend one or more phases of their life cycle within estuaries (COWLEY et al., 2001; WATT- PRINGLE; STRYDOM, 2003).

Most studies of the ichthyofauna of the shallow zone of beaches analyze the community, with no focus on each population individually. Thus, a lot of information about each species is lost, making it difficult to relate fish spawning and juvenile recruitment. The purpose of the present study is to describe the juvenile fish recruitment in the shallow zone of the beaches of the Cananéia-Iguape Coastal System, analyzing period of occurrence and the patterns of use for the most abundant sampled species.

\section{MATERIAL AND METHODS}

\section{Study Site}

The Cananéia-Iguape coastal system is located on the southern coast of São Paulo State, between the latitudes of $24^{\circ} 40^{\prime} \mathrm{S}$ and $25^{\circ} 10^{\prime} \mathrm{S}$ (Figure 1). It is considered the most protected coastal zone in São Paulo State. The average annual temperature is $23.8^{\circ} \mathrm{C}$, and the average annual precipitation is $2300 \mathrm{~mm}$ (SILVA, 1989). There is a mixed tide with an amplitude of $0.81 \mathrm{~m}$ (MESQUITA; HARARI, 1983).

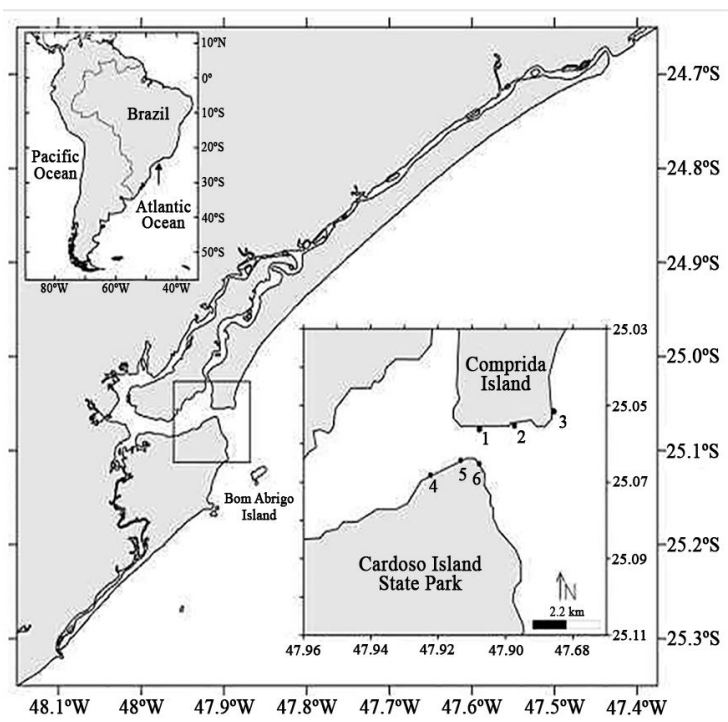

Figure 1. Location of the sampled beaches at Comprida Island and at Cardoso Island State Park, southeast Brazil.

A recent data compilation indicated that this region contains at least 246 fish species (CONTENTE, 2013). At Cardoso Island State Park (Figure 1), the spatio-temporal variation in the surf-zone fish community was studied by FAVERO and DIAS (2013).

Coastal and estuarine fisheries are an important socioeconomic activity for the inhabitants of towns bordering the Cananéia-Iguape coastal system (MENDONÇA; KATSURAGAWA, 1997; 2001). The main fish resources of the region are: Anchoviella lepidentostole, Macrodon ancylodon, Mugil liza, Mugil curema, Micropogonias furnieri and Genidens barbus (MENDONÇA; MIRANDA, 2008). 


\section{SAmpling Methods}

The beaches studied were located in the Cardoso Island State Park and on Comprida Island (Figure 1). Although no studies were found that characterize the morphology of the beaches studied, during the surveys it was observed that the further into the channel, the smaller the wave heights and more silty the sediment.

Fish were sampled monthly over one year, from February 2009 to January 2010. On each beach four consecutive hauls of approximately $30 \mathrm{~m}$ each were made using a beach seine net, $9 \mathrm{~m}$ long, $1.5 \mathrm{~m}$ high with a stretched mesh size of $5 \mathrm{~mm}$ when pulled by hand. All samples were collected at low and high spring tide. Low tide was sampled at its morning peak while the high tide was usually sampled during the afternoon, at a time close to its peak. At the start of the first haul and at the end of the last one, on each beach, the water temperature was measured with a mercury thermometer and the water salinity with a refractometer.

All fish collected were identified following FIGUEIREDO and MENEZES (1978, 1980, 2000), MENEZES and FIGUEIREDO (1980, 1985) and RICHARDS (2006). Due to the difficulty in identifying juvenile Mugilidae and the lack of taxonomic literature for the specific distinction within this family on the Brazilian southeastern coast, all mugilids collected were separated based on VIEIRA (1991). The following nomenclature was used: Mugil hospes (previously Mugil gaimardianus), and Mugil liza (previously Mugil platanus) according to MENEZES et al. (2010).

Fish were measured to the nearest $1 \mathrm{~mm}$ (standard length), except when samples were very large. On these occasions, measurements were restricted to a subsample of 50 individuals per species. The excess was counted and incorporated as number counts. In addition, sex (male, female or not identified) and maturity stages were documented for the subsample through macroscopic observation, according to VAZZOLER (1996) and DIAS et al. (1998).

\section{DATA ANALYSIS}

Analysis of variance (one way ANOVA) was used to test the significance of differences between the monthly abiotic data of water temperature and water salinity. Tukey post-hoc tests were conducted to evaluate which means differed from each other.

All the biological analyses were made using only the eight most-abundant fish species (occurrence greater than $3 \%$ ), excluding the species sampled only in the larval phase. As there were not enough individuals per species to perform a monthly analysis, the data were grouped per season as: spring $=$ September, October and November; summer $=$ December, January and February, autumn = March, April and May, winter = June, July and August.

To assess whether fish were using the beaches as growth areas, an empirical cumulative distribution function (ECDF) of standard length was performed for each species in each season. Differences in the standard length distribution per season were tested by a permutation test with a confidence level of $99 \%(p<0.01)$.

The analyses were made using the $\mathrm{R}$ program $(\mathrm{R}$ CORE TEAM, 2012).

\section{RESULTS}

Water temperature varied significantly over the year sampled, especially comparing the warmer months (November-April) with the coldest ones (May-October) (Figure 2). The maximum water temperature was $30.5^{\circ} \mathrm{C}$ in March and the minimum was $18.0^{\circ} \mathrm{C}$ in June and August.

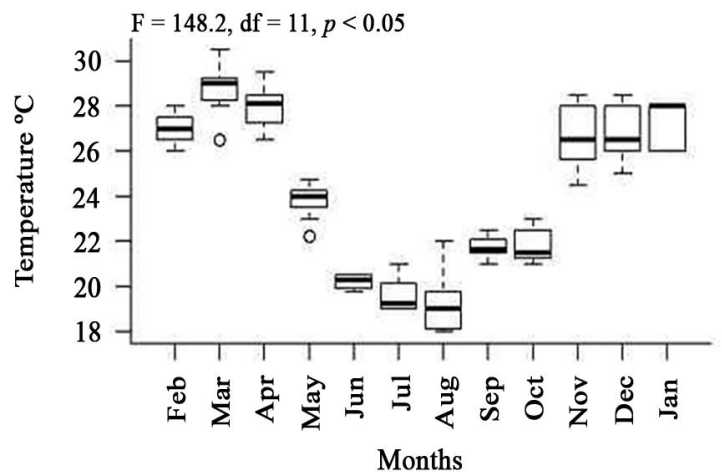

Figure 2. Monthly variation of water temperature $\left({ }^{\circ} \mathrm{C}\right)$ recorded in beaches of the Cananéia-Iguape coastal system from February 2009 to January 2010.

Despite the significant difference in water salinity in the months sampled, there was no clear variation pattern in salinity as was observed for water temperature (Figure 3 ). The salinity variation was probably due to beach localization, tide and rainfall. The maximum water salinity was 36 in June and the minimum was 12 in January.

A total of 13,861 individuals, belonging to 57 species and 24 families, were collected. Of the total, 34 were sampled at both islands, 10 were sampled only at Comprida Island, and 13 only at Cardoso Island. The fish species that were collected only at one island were rare, up to 20 individuals per species. The exception was Choloroscombrus chrysurus, which was sampled only at Cardoso Island and was abundant $(\mathrm{N}=145)$ (Table 1$)$. 


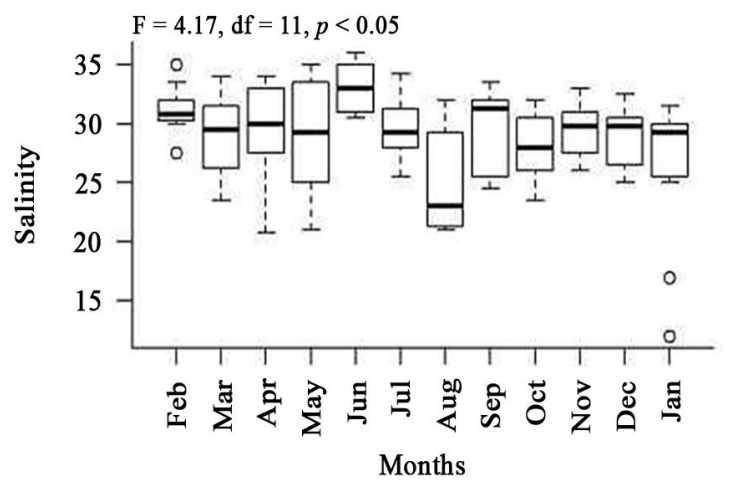

Figure 3. Monthly variation of water salinity recorded in beaches of the Cananéia-Iguape coastal system from February 2009 to January 2010.
The most-abundant species were: Mugil curema (23.01\%), Trachinotus carolinus (21.40\%), Mugil hospes (16.12\%), Gerreidae larvae (9.46\%), Trachinotus goodei (5.18\%), Atherinella brasiliensis (4.88\%), Harengula clupeola (3.68\%) and Mugil liza (3.05\%). Atherinella brasiliensis was the only species sampled as adults $(\mathrm{N}=170)$, juveniles $(\mathrm{N}=493)$ and larvae $(\mathrm{N}=1)$, and all the other fish species were sampled only as juveniles.

Carangids were abundant during all seasons. Recruitment of $T$. goodei juveniles started in spring, when approximately $70 \%$ of fish sampled were of small length (11.5 to $25 \mathrm{~mm}$ ). An increase in fish size was observed in each season from spring to winter. During the winter no

Table 1. Monthly number of the fish species sampled in the surf zone of sandy beaches located in the Cananéia-Iguape Coastal System from February 2009 to January 2010.

\begin{tabular}{|c|c|c|c|c|c|c|c|c|c|c|c|c|c|}
\hline \multirow{2}{*}{ Family/Species } & \multicolumn{12}{|c|}{ Number of individuals } & \multirow{2}{*}{ Total } \\
\hline & Feb & Mar & Apr & May & Jun & Jul & Aug & Sep & Oct & Nov & Dec & Jan & \\
\hline \multicolumn{14}{|l|}{ Elopidae } \\
\hline Elops saurus & 60 & 4 & & & & & & & 8 & 25 & & 1 & 98 \\
\hline \multicolumn{14}{|l|}{ Engraulidae } \\
\hline Anchoa januaria & 10 & & & & & & & & & & 7 & 54 & 71 \\
\hline Anchoa lyolepis & & 4 & & 1 & & & & & & & & 1 & 6 \\
\hline Anchoa tricolor & 70 & 44 & 2 & & 2 & & & & & & 6 & 247 & 371 \\
\hline Anchoviella lepidentostole & 1 & 4 & & & & & 4 & & & & & 19 & 28 \\
\hline Cetengraulis edentulus & & & 40 & & & & & & & & & 6 & 46 \\
\hline Lycengraulis grossidens & 1 & 1 & & & & & & & & & & & 2 \\
\hline Engraulidae larvae & 22 & 15 & 23 & 23 & 33 & 12 & 3 & & 21 & 40 & & 7 & 199 \\
\hline \multicolumn{14}{|l|}{ Clupeidae } \\
\hline Harengula clupeola & 13 & 34 & 22 & 6 & & 321 & 41 & 43 & 7 & 7 & & 16 & 510 \\
\hline Opisthonema oglinum & & & 2 & & & & & & & & & 1 & 3 \\
\hline Platanichthys platana & & & & & & & & & & & 1 & & 1 \\
\hline Sardinella brasiliensis & & & & & & & & & & & 6 & & 6 \\
\hline \multicolumn{14}{|l|}{ Synodontidae } \\
\hline Synodus foetens & 1 & & & & & & 1 & & & & & & 2 \\
\hline Batrachoididae & & & & & & & & & 1 & & & & 1 \\
\hline Porichthys porosissimus & & & & & & & & & 0 & & & & \\
\hline \multicolumn{14}{|l|}{ Mugilidae } \\
\hline Mugil curema & 11 & 5 & 1 & 13 & 3 & & & 3 & 36 & 53 & 2963 & 102 & 3190 \\
\hline Mugil hospes & 15 & 20 & 21 & 19 & 6 & & & & 1 & 155 & 1879 & 118 & 2234 \\
\hline Mugil liza & 2 & & 1 & 1 & 11 & 130 & 165 & 13 & 50 & 12 & 37 & 1 & 423 \\
\hline Mugil sp. 1 & 1 & & & & 2 & & & & 2 & 3 & 117 & 3 & 128 \\
\hline Mugil sp. 2 & & & & & 1 & 1 & 1 & & & & & & 3 \\
\hline \multicolumn{14}{|l|}{ Atherinopsidae } \\
\hline Atherinella brasiliensis & 20 & 77 & 25 & 12 & 22 & 118 & 75 & 86 & 49 & 15 & 9 & 168 & 676 \\
\hline Odontesthes argentinensis & & & 1 & & & 1 & & 1 & 2 & 1 & 1 & & 7 \\
\hline
\end{tabular}




\section{Continued Table 1.}

\begin{tabular}{|c|c|c|c|c|c|c|c|c|c|c|c|c|c|}
\hline \multicolumn{14}{|l|}{ Hemiramphidae } \\
\hline Hemiramphus sp. & 1 & & & & & & & & & & & & 1 \\
\hline Hyporhamphus unifasciatus & & & & & & & & & & & 1 & & 1 \\
\hline \multicolumn{14}{|l|}{ Belonidae } \\
\hline Strongylura marina & & & & & & & & & & & 1 & & 1 \\
\hline Strongylura tiтиси & & 4 & 5 & 1 & & & & & & 24 & & 4 & 38 \\
\hline Tylosurus acus & & & & & & & & & & 2 & & & 2 \\
\hline \multicolumn{14}{|l|}{ Syngnathidae } \\
\hline Syngnathus folletti & & & & & & & & & & 1 & & 1 & 2 \\
\hline \multicolumn{14}{|l|}{ Serranidae } \\
\hline Mycteroperca tigris & & & & & & & & & & 3 & & & 3 \\
\hline Mycteroperca sp. & & & & & & & & & & 4 & & & 4 \\
\hline \multicolumn{14}{|l|}{ Pomatomidae } \\
\hline Pomatomus saltatrix & 1 & & & & & 3 & & & 1 & 1 & 2 & & 8 \\
\hline \multicolumn{14}{|l|}{ Carangidae } \\
\hline Caranx latus & & 3 & & & & & & & & & 58 & & 61 \\
\hline Choloroscombrus chrysurus & & & & & & & & & & & 145 & & 145 \\
\hline Oligoplites saliens & 16 & 12 & 14 & 7 & 4 & 19 & 15 & 3 & 2 & 8 & 90 & 41 & 231 \\
\hline Oligoplites sp. & & 1 & & & & & & & & & & 1 & 2 \\
\hline Selene vomer & & 2 & & & & & & & & & & & 2 \\
\hline Trachinotus carolinus & 272 & 138 & 182 & 139 & 95 & 28 & 5 & 14 & 72 & 273 & 1516 & 232 & 2966 \\
\hline Trachinotus falcatus & 4 & 1 & 1 & & & & & & & 17 & 4 & 2 & 29 \\
\hline Trachinotus goodei & 58 & 70 & 54 & 114 & 30 & 39 & 2 & 10 & 42 & 112 & 116 & 71 & 718 \\
\hline \multicolumn{14}{|l|}{ Lobotidae } \\
\hline Lobotes surinamensis & 1 & & & & & & & & & & & & 1 \\
\hline \multicolumn{14}{|l|}{ Gerreidae } \\
\hline Gerreidae larvae & 142 & 50 & 238 & 10 & & & & & 3 & 806 & 44 & 18 & 1311 \\
\hline \multicolumn{14}{|l|}{ Haemulidae } \\
\hline Pomadasys corvinaeformis & & 2 & 2 & & & & & & & & & & 4 \\
\hline \multicolumn{14}{|l|}{ Polynemidae } \\
\hline Polydactylus oligodon & & & & & & & & & 1 & & & & 1 \\
\hline Polydactylus virginicus & & & & & & & & & & 1 & & & 1 \\
\hline \multicolumn{14}{|l|}{ Sciaenidae } \\
\hline Menticirrhus americanus & & & 1 & & & & & 2 & 15 & 26 & & & 44 \\
\hline Menticirrhus littoralis & 2 & 2 & 6 & 20 & 3 & 33 & 15 & 10 & 17 & 61 & 33 & 23 & 225 \\
\hline Micropogonias furnieri & & & & & & 1 & & & & 4 & & & 5 \\
\hline Umbrina coroides & & & & & & 1 & & & & & & & 1 \\
\hline \multicolumn{14}{|l|}{ Pomacentridae } \\
\hline Abudefduf saxatilis & 1 & & & & & & & & & 2 & & & 3 \\
\hline \multicolumn{14}{|l|}{ Blenniidae } \\
\hline Parablennius pilicornis & 1 & & & & & & & & & & & & 1 \\
\hline \multicolumn{14}{|l|}{ Paralichthyidae } \\
\hline Citharichthys arenaceus & & & & & & & & & 2 & & & & 2 \\
\hline Etropus crossotus & 1 & & & & & & & & 18 & & & & 19 \\
\hline
\end{tabular}


Continued Table 1.

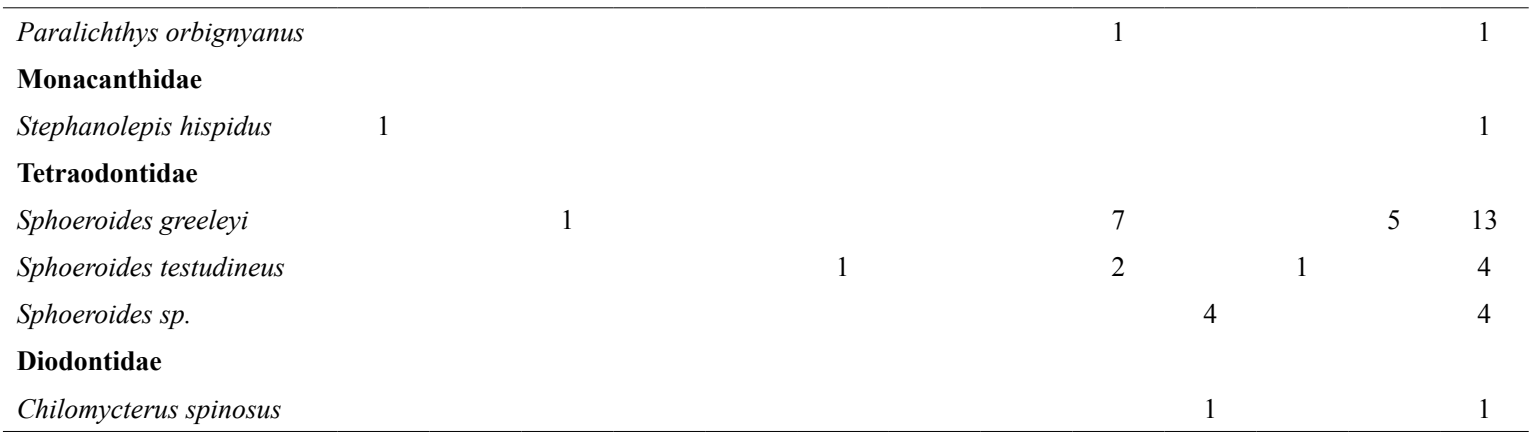

fish smaller than $30 \mathrm{~mm}$ were sampled, and a high percentage of individuals larger than $50 \mathrm{~mm}$ was recorded (Figure 4). The minimum and the maximum standard length for $T$. goodei was $11.50 \mathrm{~mm}$ and $152 \mathrm{~mm}$, both observed in spring. Trachinotus goodei was more abundant in summer $(\mathrm{N}=245)$, then in autumn $(\mathrm{N}=238)$, followed by spring $(\mathrm{N}=164)$ and winter $(\mathrm{N}=71)$.

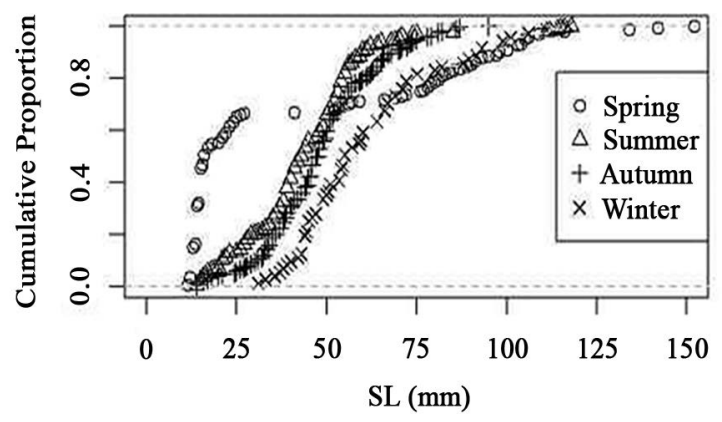

Figure 4. Empirical cumulative distribution function (ECDF) of standard length (SL) of Thachinotus goodei sampled in beaches of the Cananéia-Iguape coastal system from February 2009 to January 2010.

Although the permutation test showed significant differences between the standard lengths in different seasons, no clear pattern of individuals' growth was observed for T. $c a$ rolinus, as small-sized individuals were abundant during all seasons (Figure 5). The minimum standard length observed was $1.5 \mathrm{~mm}$ during winter and the maximum was $70 \mathrm{~mm}$ in spring. As observed for T. goodei, T. carolinus was more abundant in summer $(\mathrm{N}=1,213)$, than in autumn $(\mathrm{N}=458)$, followed by spring $(\mathrm{N}=359)$ and winter $(\mathrm{N}=128)$.

A small range of standard length was observed for mugilids. Most of them measured from $20 \mathrm{~mm}$ to $30 \mathrm{~mm}$. No pattern of individual growth through the seasons was observed due to the small size range. This fact combined with the presence of the individuals in all seasons, suggests a constant input of juveniles during the year, but with

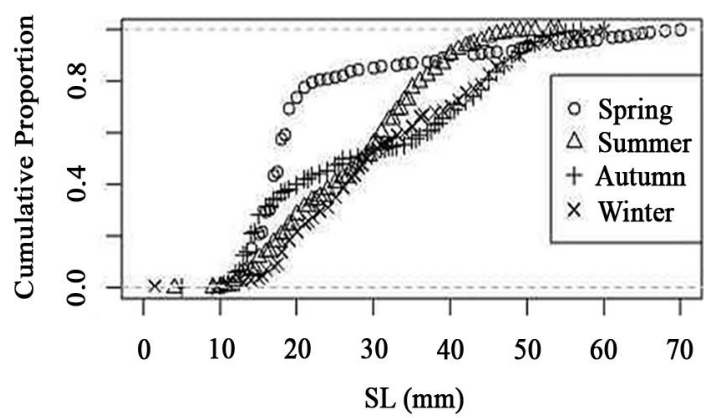

Figure 5. Empirical cumulative distribution function (ECDF) of standard length (SL) of Thachinotus carolinus sampled in beaches of the CananéiaIguape coastal system from February 2009 to January 2010.

greater abundance at different times: $M$. curema and $M$. hospes during summer and $M$. liza during winter (Table 2).

Table 2. Total number of mugilids sampled in the surf zone of the Costal System Cananéia-Iguape from February 2009 to January 2010.

\begin{tabular}{lccccc}
\hline & Autumn & Spring & Summer & Winter & Total \\
\hline Mugil curema & 19 & 92 & 426 & 3 & 540 \\
Mugil hospes & 60 & 80 & 385 & 6 & 531 \\
Mugil liza & 2 & 75 & 11 & 275 & 363 \\
\hline
\end{tabular}

Atherinella brasiliensis was the only species with representatives in all phases of gonadal development in the study area (Figure 6). Small-size individuals were abundant in summer, with dominance of the $40-60 \mathrm{~mm}$ size class. In subsequent seasons, it was possible to observe a significant increase in the size of the individuals (Figure 7). The high abundance of maturing individuals from September to November was related to the high abundance of individuals in the largest size class in spring. Furthermore, $97 \%$ of the fish sampled in January were immature, being related to the smallest size class observed in summer (Figure 6 and Figure 7). 


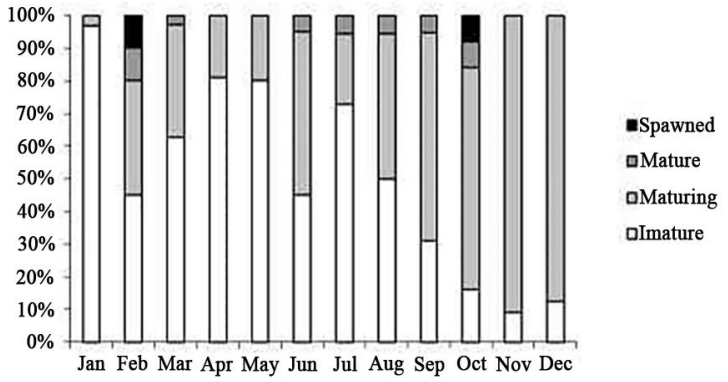

Figure 6. Monthly frequency of occurrence of the gonadal stages of Atherinella brasiliensis sampled in the surf zone of sandy beaches located in the Cananéia-Iguape coastal system from February 2009 to January 2010 .

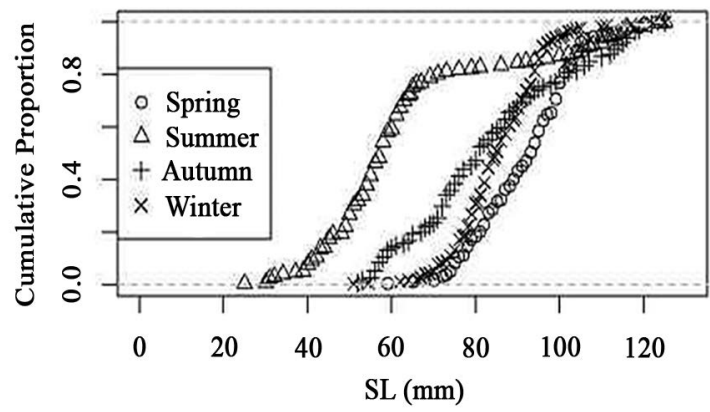

Figure 7. Empirical cumulative distribution function (ECDF) of standard length (SL) of Atherinella brasiliensis sampled in beaches of the Cananéia-Iguape coastal system from February 2009 to January 2010.

Small-size individuals of $H$. clupeola were collected only in summer. The greatest abundance of this species occurred in winter, when most of the fish measured from 55 $\mathrm{mm}$ to $65 \mathrm{~mm}$. Even though the permutation test showed significant results between the different standard lengths in the different seasons, there was no clear pattern of individuals' growth (Figure 8).

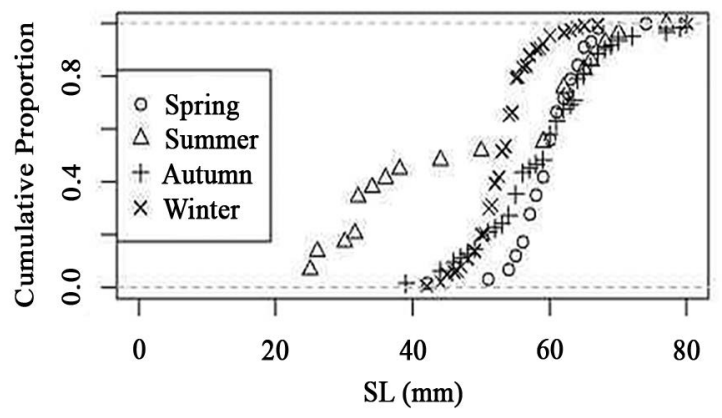

Figure 8. Empirical cumulative distribution function (ECDF) of standard length (SL) of Harengula clupeola sampled in beaches of the Cananéia-Iguape coastal system from February 2009 to January 2010.

\section{DISCUSSION}

Closed areas where juveniles aggregate have often been assumed to benefit recruitment by reducing the mortality of undersized individuals (WRIGHT et al., 2010). Surf zones of sandy beaches have this function, as resident fish are a minority and most species present are represented by young seasonal or sporadic migrants (MCLACHLAN, 1983).

Considering that resident species are only those that spend their entire life cycle and the whole year in the same area, only $A$. brasiliensis can be considered as resident at the beaches sampled, even though they undergo some little migration from the beach to the river (FERNANDEZ, 2007). No resident species were observed by FÉLIX et al. (2007a) on the beaches of Pontal do Sul, in Paraná State. MODDE (1980) classified six fish species as resident in the surf zone of beaches of the Gulf of Mexico, but there were no analyses of the maturity stage, and the classification was based only on the individuals' size classes and the monthly frequency of occurrence. MODDE (1980) points out that more than half of the fish caught were juvenile migrants which may have been using the area as a refuge or as migratory route. According to LAYMAN (2000), most of the fish species collected were classified as seasonal juveniles using the shallow water as nurseries, or transient adults, which were more abundant in other marine habitats.

No matter the fishing gear used, all the species analyzed in this study were also sampled inside the Cananéia-Iguape coastal system or close to its mouth (ZANI-TEIXEIRA, 1983; MACIEL, 2001). Harengula clupeola, M. curema, T. carolinus and $T$ goodei were also sampled at Bom Abrigo Island, an island located just outside the coastal system studied (SAUL; CUNNINGHAM, 1995). In addition, Cananéia fisheries' landing data reported the occurrence of T. carolinus and T. goodei outside the estuary (MENDONÇA; KATSURAGAWA, 1997), while mugilids were an important estuarine fishery resource in the Cananéia-Iguape coastal system (MENDONÇA; KATSURAGAWA, 2001). These facts reinforce the idea that the fish species studied are recruited as young-of-the-year on these beaches, and use the beaches only during a short time. In general, the main inter-season changes in abundance and community 
structure were due to the variation of the key species and reflected the different times of their recruitment (SELLESLAGH; AMARA, 2008).

The genus Trachinotus inhabits coastal areas, frequently in the surf zone of beaches (MENEZES; FIGUEIREDO, 1980). Several studies of Brazilian beaches (GIANNINI; PAIVA FILHO, 1995; GODEFROID et al., 2003; VASCONCELLOS et al., 2007; GAELZER; ZALMON, 2008; FAVERO; DIAS, 2013) and beaches elsewhere (MODDE, 1980; SANTOS; NASH, 1995; LAYMAN, 2000) indicate high abundance of juveniles of this genus in such habitats. However, information on the spawning sites and seasons remains sparse, which makes it difficult to interpret the Trachinotus recruitment pattern in the study area.

Trachinotus goodei usually occurs in the surf zone of sandy beaches forming large shoals associated with saline waters, while T. carolinus occurs in small or large shoals along sandy beaches, inlets and bays with brackish water (CARPENTER, 2002). Apparently, juvenile T. goodei recruit in the study area mainly in spring, showing a clear pattern of seasonal growth during the year, while T. carolinus recruits throughout the year, as previously described by FÉLIX et al. (2007b).

As $T$. goodei were sampled in length classes larger than those of T. carolinus, it is possible to conclude that the beach seine selectivity did not influence the capture of T. carolinus. This confirms that T. carolinus larger than 60 $\mathrm{mm}$ migrate to deeper water (FIELDS, 1962; MODDE, 1980; FÉLIX et al., 2007a). Probably the spawning of T. carolinus occurs in oceanic waters (CARPENTER, 2002). The fishing method probably was size selective for $T$. goodei, because mature individuals of this species had previously been sampled at Atami Beach, in southern Brazil (GODEFROID et al., 2003) and, during our sampling days, several people fishing with hook and line were observed catching T. goodei larger than those captured with the beach seine.

Mugilids are coastal fishes that are found abundantly in estuaries. Small-size individuals are very abundant in the shallow zone of sandy beaches, mainly near river mouths (MENEZES; FIGUEIREDO, 1985). Usually, they spawn in oceanic waters, but afterwards move into coastal areas, entering estuaries and rivers, where they settle (MENEZES; FIGUEIREDO, 1985; VIEIRA; SCALABRIN, 1991; CHANG, 2000; SILVA, 2007).

In the present study, a small variation was noticed in the individuals' lengths throughout the year, but there was no clear pattern of seasonal growth for the mugilid species. The higher abundance of $M$. curema and $M$. hospes during summer, and of M. liza during winter was also observed in a Brazilian coastal lagoon (VIEIRA, 1991). There was also a greater abundance of M. liza juveniles during July and September in the surf zone of a beach located in southern Brazil (VIEIRA; SCALABRIN, 1991).

As we obtained specimens of other species larger than $100 \mathrm{~mm}$ standard length, it is believed that the small size range in which most mugilids were collected is not caused by the beach seine selectivity. Two hypotheses have been suggested to explain this small size range: 1) Mugilids are fast swimmers (RULIFSON, 1977), so bigger individuals can avoid the beach seine net, which is pulled by hand, at low speed. 2) Small-size mugilids use the beaches sampled as a route from the ocean to the estuary.

The reproductive period varies according to species and area studied. The spawning period of $M$. liza is from September to November in Paranaguá Bay (ESPER et al., 2001) and from June to October in Cananéia (ANDRADE-TALMELLI et al., 1996). VIEIRA and SCALABRIN (1991) reported that $M$. liza migration from the Patos Lagoon (south Brazil) to oceanic waters starts in April and May (autumn), with the spawning peak in May and June. Those authors also indicated that the juvenile recruitment occurs throughout the year, especially during the winter and spring.

The Mugil curema spawning period is from February to May in the Gulf of Mexico (AGUIRRE; GALLARDO-CABELLO, 2004), while along the coast of São Paulo State, M. curema from the Cananéia-Iguape coastal system and from the Santos estuary showed the beginning of gonadal maturation in October, which extended to April, with two annual spawning events, one in April and another in November (FERNANDEZ; DIAS, 2013), whereas around Santos it occurred in late spring and early summer (CERGOLE, 1986; FERREIRA, 1989). Spawning individuals migrated offshore from a coastal lagoon in Venezuela from September until January, and the juvenile fish recruited to the lagoon mainly between March and June (MARÍN et al., 2003). Thus, the gap between the spawning period described for M. liza and $M$. curema and the juvenile recruitment period at the beaches sampled, corroborates the second hypothesis presented above. 
Atherinella brasiliensis was the only species represented by mature and spent females. However, no hydrated oocytes were observed. As oocyte hydration is a short term process (less than 8 hours) and indicates imminent spawning (HUNTER; GOLDBERG, 1980; DIAS et al., 1998), it is possible to conclude that $A$. brasiliensis does not use the surf zone to spawn during the daytime or leaves the surf zone for final maturation. As this species migrates daily, leaving the Itamambuca beach surf zone and going to the Itamambuca River to spawn (FERNANDEZ, 2007), in the study area the spawning probably occurs inside the estuary or in a small river close to the most internal beach at Cardoso Island (beach number 4 in Figure 1). Additionally, Atherinopsidae eggs have filaments that are used to stick in the aquatic vegetation (HUAQUÍN, 1980; MARÍN et al., 1995). This helps to understand why the females do not spawn at the beaches sampled, as there is no vegetation to serve as substrate for eggs.

Atherinella brasiliensis spawns throughout the year in the Cananéia-Iguape coastal system, more intensely during winter and spring (PERES-RIOS, 2001). This may be related to the juveniles' recruitment at the beaches sampled, during summer. PESSANHA and ARAÚJO (2001) and FERNANDEZ (2007) also indicated that summer was the recruitment season of A. brasiliensis on beaches. In the Paranaguá Bay estuarine complex, A. brasiliensis distribution among size classes varied significantly across seasons, with larger fish prevailing during winter and spring (reproductive period), resulting in the high abundance of recruits of the year during the summer (FÁVARO et al., 2003; CONTENTE et al., 2011). The same patterns of annual growth and recruitment were observed in the area here studied.

Even with the occurrence of Sardinella brasiliensis and Opisthonema oglinum, H. clupeola was the only abundant clupeid species. The high abundance of $H$. clupeola in the surf zone of Brazilian sandy beaches has previously been reported by several authors (GIANNINI; PAIVA FILHO, 1995; PESSANHA; ARAÚJO, 2003; VASCONCELLOS et al., 2007; GAELZER; ZALMON, 2008), especially during the winter, as in the present study (SAUL; CUNNINGHAM, 1995; FÉLIX et al., 2007a). This species has its juvenile phase in the Cananéia-Iguape coastal system, mainly at the beaches (PERES-RIOS, 2001).
Although juveniles of Gerreidae are among the most abundant groups in the coastal ecosystems, including those caught in beach seine samples (ARAÚJO; SANTOS, 1999; FÉLIX et al., 2007a; 2007b; SOUZA-CONCEIÇÃO et al., 2013; PEREIRA et al., 2014), they were only sampled in the larval stage in the study area. Araújo and Santos (1999) found that juvenile gerreids prefer less-turbid regions, with mud and moderate organic matter substrates, while GODEFROID et al. (1999; 2001) found 98\% of gerreids in the larval stage, corroborating the findings of this study.

The present study highlights the importance of the sandy beaches for juvenile fish, whether as a migration route or as a growth area, especially in spring and summer when most juveniles recruit. Unfortunately, this period is the one with the greatest tourism impact. PEREIRA et al. (2014) indicated that less anthropogenic disturbance on the beach results in greater fish richness and abundance. It is also important to note that many of the species studied are commercially important, emphasizing the necessity of coastal habitat preservation for better fishery management.

\section{ACKNOWLEDGMENTS}

The authors would like to thank all the IOUSP volunteers and employees involved in the fieldwork and fish identification. We also thank $\mathrm{CNPq}$, which has granted the author's postgraduate scholarship, Dr. Carlos A. Assis for reviewing the manuscript and Dr. Jefferson T. Turner for the English editing.

\section{REFERENCES}

AGUIRRE, A. L. I.; GALLARDO-CABELLO, M. Reproduction of Mugil cephalus and M. curema (Pisces: Mugilidae) from a coastal lagoon in the Gulf of México. Bull. Mar. Sci., v. 75, n. 1, p. $37-49,2004$.

ANDRADE-TALMELLI, E. F. A.; ROMAGOSA, E.; NARAHARA, M. Y.; GODINHO, H. M. Características reprodutivas de Tainha Mugil platanus (Teleostei, Perciformes, Mugilidae) da região Estuarino-Lagunar de Cananéia, São Paulo. Rev. Ceres, v. 43, n. 246, p. 165-185, 1996.

ARAÚJO, F. G.; SANTOS, A. C. A. Distribution and recruitment of Mojarras (Perciformes, Gerreidae) in the continental margin of Sepetiba Bay, Brazil. Bull. Mar. Sci., v. 65, n. 2, p. 431-439, 1999.

CARPENTER, K. E. (Ed.) The living marine resource of the western central Atlantic. Volume 3: Bony fishes part 2 (Opistognathidae to Molidae), sea turtles and marine mammals. Food Agriculture Organization of the United Nations. Rome, 2002. 
CERGole, M. C. Aspectos sobre a biologia de M. curema VALLENCINES, 1836 (Pisces, Mugilidae) no estuário de São Vicente, SP. 272 f. Dissertation (Master in Biological Oceanography)- Instituto Oceanográfico, Universidade de São Paulo, São Paulo, 1986.

CHANG, C. W.; TZENG, W. N.; LEE, Y. C. Recruitment and Hatching Dates of Grey Mullet (Mugil cephalus L.) Juveniles in the Tanshui Estuary of Northwest Taiwan. Zool. Stud., v. 39, n. 2, p. 99-106, 2000

CLARK, B. M.; BENNETT, B. A.; LAMBERT, S. J. Factors affecting spatial variability in seine net catches of fish in the surf zone of False Bay, South Africa. Mar. Ecol. Prog. Ser., v. 131, p. 17-34, 1996b.

CONTENTE, R. F. Padrões ecológicos locais e multidecadais da ictiofauna do estuário Cananéia-Iguape. 185 f. Tese (Doutorado em Oceanografia Biológica)- Instituto Oceanográfico, Universidade de São Paulo, São Paulo, 2013.

CONTENTE, R. F.; STEFANONI, M. F.; SPACH, H. L. Feeding ecology of the Brazilian silverside Atherinella brasiliensis (Atherinopsidae) in a sub-tropical estuarine ecosystem. J. Mar. Biol. Assoc. U.K., v. 91, n. 6, p. 1197$1205,2011$.

COWLEY, P. D.; WHITFIELD, A. K.; BELL, K. N. I. The surf zone ichthyoplankton adjacent to an intermittently open estuary, with evidence of recruitment during marine overwash events. Estuar. Coast. Shelf Sci., v. 52, n. 3, p. 339-348, 2001.

DIAS, J. F.; PERES-RIOS, E.; CHAVES, P. T. C.; ROSSI-WONGTSCHOWSKI, C. L. D. B. Análise macroscópica dos ovários de teleósteos: problemas de classificação e recomendações de procedimentos. Rev. Bras. Biol., v. 58, n. 1 , p. 55-69, 1998.

ESPER, M. L. P.; MENEZES, M. S.; ESPER, W. Época reprodutiva de Mugil platanus (Günther, 1880), Pisces Mugilidae da Baia de Paranaguá (Paraná, Brasil). Acta Biol. Par., v. 30, n. 1, 2, 3, 4, p. 5-17, 2001.

FÁVARO, L. F.; LOPES, S. C. G.; SPACH, H. L. Reprodução do peixe, Atherinella brasiliensis (Quoy \& Gaimard) (Atheriniformes, Atherinidae), em uma planície de maré adjacente à gamboa do Baguaçu, Baía de Paranaguá, Paraná, Brasil. Rev. Bras. Zool., v. 20, n. 3, p. 501-506, 2003.

FAVERO, J. M.; DIAS. J. F. Spatio-temporal variation in surf zone fish communities at Ilha do Cardoso State Park, São Paulo, Brazil. Lat. Am. J. Aquat. Res., v. 41, n. 2, p. 239253, 2013.

FÉLIX, F. C.; SPACH, H. L.; Moro, P. S.; HACKRADT, C. W.; QUEIROZ, G. M. L. N.; HOSTIM-SILVA, M. Icthyofauna composition across a wave-energy gradient on southern Brazil beaches. Braz. J. Oceanogr., v. 55, n. 4, p. 281-292, 2007a.

FÉLIX, F. C.; SPACH, H. L.; MORO, P. S.; SCHWARZ JR. R.; SANTOS, C.; HACKRADT, C. W.; HOSTIM-SILVA, M. Utilization pattern of surf zone inhabiting fish from beaches in Southern Brazil. Pan-Am. J. Aquat. Sci., v. 2, n. 1, p. 27-39, 2007b.

FERNANDEZ, W. S. Dinâmica populacional de Atherinella brasiliensis (Quoy \& Gaimard, 1824) da Praia de Itamambuca, Ubatuba. $144 \mathrm{f}$. Dissertation (Master in Biological Oceanography)- Instituto Oceanográfico, Universidade de São Paulo, São Paulo, 2007.
FERNANDEZ, W. S.; DIAS, J. F. Aspects of the reproduction of Mugil curema Valenciennes, 1836 in two coastal systems in southeastern Brazil. Trop. Zool., v. 26, n. 1, p. 15-32, 2013.

FERREIRA, L. I. Estudos de aspectos da reprodução de $M u$ gil curema Vallenciennes, 1836 (Pisces, Mugilidae) no estuário de São Vicente. $90 \mathrm{f}$. Dissertation (Master in Biological Oceanography)- Instituto Oceanográfico, Universidade de São Paulo, São Paulo, 1989.

FIELDS, H. M. Pompanos (Trachinotus spp.) of South Atlantic coast of United States. Fish. Bull., v. 207, n. 62, p. 189-222, 1962

FIGUEIREDO, J. L.; MENEZES, N. A. Manual de peixes marinhos do sudeste do Brasil. II. Teleostei (1). São Paulo: Museu de Zoologia da Universidade de São Paulo, 1978. $110 \mathrm{p}$.

FIGUEIREDO, J. L.; MENEZES, N. A. Manual de peixes marinhos do sudeste do Brasil. III. Teleostei (2). São Paulo: Museu de Zoologia da Universidade de São Paulo, 1980. $90 \mathrm{p}$.

FIGUEIREDO, J. L.; MENEZES, N. A. Manual de peixes marinhos do sudeste do Brasil. VI. Teleostei (5). São Paulo: Museu de Zoologia da Universidade de São Paulo, 2000. 116 p.

GAELZER, L. R.; ZALMON, I. R. Diel variation of fish community in sandy beaches of southeastern Brazil. Braz. J. Oceanogr., v. 56, n. 1, p. 23-39, 2008.

GIANNINI, R.; PAIVA FILHO, A. M. Análise comparativa da ictiofauna da zona de arrebentação de praias arenosas do Estado de São Paulo, Brasil. Bol. Inst. Oceanogr., v. 43, n. 2, p. 141-152, 1995.

GODEFROID, R. S; HOFSTAETTER, M.; SPACH, H. L. Larval fish in the surf zone of Pontal do Sul beach, Pontal do Parana, Parana, Brazil. Rev. Bras. Zool., v. 16, n. 4, p. 1005-1011, 1999.

GODEFROID, R. S; SANTOS, C.; HOFSTAETTER, M.; SPACH, H. L. Occurrence of Larvae and Juveniles of Eucinostomus argenteus, Eucinostomus gula, Menticirrhus americanus, Menticirrhus littoralis, Umbrina coroides and Micropogonias furnieri at Pontal do Sul beach, Paraná. Braz. Arch. Biol. Technol., v 44, n 4, p. 411-418, 2001.

GODEFROID, R. S.; SPACH, H. L.; SANTOS, C.; MACLAREN, G.; SCHWARZ JR, R.; A fauna de peixes da praia do Balneário Atami, Paraná, Brasil. Atlântica., v. 25, n. 2, p. 147-161, 2003.

HARDEN JONES, F. R. Fish migration. London: Edward Arnold, $1968.325 \mathrm{p}$.

HJORT, J. Fluctuations in the great fisheries of northern Europe viewed in the light of biological research. J. Cons-Cons. Perm. Int. Explor. Mer., v. 20, p. 1-228, 1914.

HUAQUÍM, L.G. Filamentos coriales en ovócitos y huevos de Basilichthys australis Elgenmann (Osteichthyes: Atherinidae). Arquiv. Biol. Med. Exp., v. 13, n. 1, p. 70, 1980.

HUNTER, J. R.; GOLDBERG, S. R. Spawning incidence and batch fecundity in Northern Anchovy Engraulis mordax. Fish. Bull., v. 77, n. 3, p.641-652, 1980.

JENNINGS, S.; KAISER, M. J.; REYNOLDS, J. D. Marine Fisheries Ecology. USA: Blackwell Science, 2001. 
LASIAK, T. A. Nursery grounds of juvenile teleosts: evidence from the surf-zone of King's Beach, Port Elizabeth. S. Afr. J. Mar. Sci., v. 77, p. 388-390, 1981.

LAYMAN, C. A. Fish Assemblage Structure of the Shallow Ocean Surf-Zone on the Eastern Shore of Virginia Barrier Islands. Estuar. Coast. Shelf Sci., v.51, n. 2, p. 201-213, 2000 .

MACIEL, N. A. L. Composição, Abundância e distribuição espaço-temporal da ictiofauna do Complexo Estuarino Lagunar de Iguape-Cananéia- São Paulo, Brasil. 252 f. Thesys (Doctor in Biological Oceanography)- Instituto Oceanográfico, Universidade de São Paulo, São Paulo, 2001.

MARÍN, B. J.; QUINTERO A.; BUSSIÈRE, D.; DODSON, J.J. Reproduction and recruitment of White Mullet (Mugil curema) to a tropical lagoon (Margarita Island, Venezuela) as revealed by otolith microstructure. Fish. Bull., v. 101, n. 4, p. 809-821, 2003.

MARÍN, B. M.; DIAZ, O.; BRICEÑO, R. Aspectos descriptivos de los ovócitos y postlarva de tinicalo Xenomelaniris brasiliensis (Quoy \& Gaimard) (Pisces: Atherinidae). Bol. Inst. Oceanogr., v. 34, n. 1/2, p. 59-68, 1995.

MCLACHLAN A. Sandy beach ecology- a review. In: MACLACHLAN A.; ERASMUS, T. (Eds). Sandy beaches as ecosystems. Junk: The Hague, 1983. p.321-380.

MCLACHLAN, A., ERASMUS, T., VAN DER HORST, G., ROSSOUW G., LASIAK, T. A.; MCGMYNNE, L. Sand beach energetics: an ecosystem approach towards a high energy interface Estuar. Coast. Shelf Sci., v. 13, n. 1 p. 11-25, 1981.

MENDONÇA, J. T.; KATSURAGAWA, M. Desembarque da pesca costeira em Cananéia (São Paulo), Brasil, durante 1995 e 1996. Nerítica, v. 11, p.1965-190, 1997.

MENDONÇA, J. T.; KATSURAGAWA, M. Caracterização da pesca artesanal no complexo estuarino-lagunar de Cananéia-Iguape, Estado de São Paulo, Brasil (1995-1996). Acta Sci., v.23, n.2, p. 535-547, 2001.

MENDONÇA, J. T.; MIRANDA, L. V. Estatística pesqueira do litoral sul do estado de São Paulo: subsídios para a gestão compartilhada. Pan-Am. J. Aquat. Sci., v.3, n.3, p.152-173, 2008.

MENEZES, N. A.; FIGUEIREDO, J. L. Manual de peixes marinhos do sudeste do Brasil. IV. Teleostei (3). São Paulo: Museu de Zoologia da Universidade de São Paulo, $1980.96 \mathrm{p}$.

MENEZES, N. A.; FIGUEIREDO, J. L. Manual de peixes marinhos do sudeste do Brasil. V. Teleostei (4). São Pau1o: Museu de Zoologia da Universidade de São Paulo, 1985. $105 \mathrm{p}$.

MENEZES, N. A.; OLIVEIRA, C.; NIRCHIO, N. An old taxonomic dilemma: the identity of the western south Atlantic lebranche mullet (Teleostei: Perciformes: Mugilidae). Zootaxa, v. 2519, p. 59-68, 2010.

MESQUITA, A. R.; HARARI, J. Tides and tide gauges of Cananéia and Ubatuba - Brazil (Lat $24^{\circ}$ ). Relat. Int. Inst. Oceanogr., São Paulo, v. 11, p. 1-14, 1983.

MODDE, T. Growth and residency of juvenile fishes within a surf zone habitat in the Gulf of México. Gulf Res. Rep., v. 6, n. 4 , p. $377-385,1980$.
PEREIRA, H. H.; NEVES, L. M.; COSTA, M. R.; ARAÚJO, F. G. Fish assemblage structure on sandy beaches with different anthropogenic influences and proximity of spawning grounds. Mar. Ecol., p. 1-12, 2014.

PERES-RIOS, E. Papel do estuário no ciclo de vida das espécies dominantes da ictiofauna do Complexo Estuarino. Lagunar de Cananéia, Iguape. $128 \mathrm{f}$. Thesis (Doctoral in Biological Oceanography)- Instituto Oceanográfico, Universidade de São Paulo, São Paulo, 2001.

PESSANHA, A. L. M.; ARAÚJO F. G. Recrutamento do peixe-rei Xenomelaniris brasiliensis (Atheriniformes, Atherinopsidae), na margem continental da Baía de Sepetiba, Rio de Janeiro, Brasil. Rev. Bras. Zool., v. 18, n. 4, p. 1265-1274, 2001.

PESSANHA, A. L. M.; ARAÚJO, F. G. Spatial, temporal and diel variations of fish assemblages at two sandy beaches in the Sepetiba Bay, RJ. Estuar. Coast. Shelf Sci., v. 57, n. 5-6, p. 817-828, 2003.

R CORE TEAM. R: A language and environment for statistical computing. R Foundation for Statistical Computing, Vienna, Austria. ISBN 3-900051-07-0. Available from: $<$ http://www.R-project.org/>. Acessed in: 2012.

RICHARDS, W. J. Early stages of Atlantic Fishes: an identification guide for the Western Central North Atlantic. Boca Raton: CRC Press, 2006. 2640p.

RULIFSON, R. A. Temperature and water velocity effects on the swimming performances of young-of-the-year striped mullet (Mugil cephalus), spot (Leiostomus xanthurus), and pinfish (Lagodon rhomboides). J. Fish. Res. Board Can., v. 34, p. 2316-2322, 1977.

SANTOS, R. S.; NASH, R. D. M. Seasonal changes in a sandy beach fish assemblage at Porto Pim, Faial, Azores. Estuar. Coast. Shelf Sci., v. 41, n. 6, p. 579-591, 1995.

SAUL, A. C.; CUNNINGHAM, P. T. M. Comunidade ictiofaunística da ilha do Bom Abrigo, Cananéia.Brasil. 2Lanço. Arq. Biol. Tecnol., v. 38, n. 4, p. 1053-1069, 1995.

SELLESLAGH, J.; AMARA, R. Inter-season and interannual variations in fish and macrocrustacean community structure on an eastern English Channel sandy beach: influence of environmental factors. Estuar. Coast. Shelf Sci., v. 77, n.4, p.721-730, 2008.

SILVA, F. M. S. Biologie, Pêche et Dynamique de la Population de Mulet Blanc (Mugil curema, Valenciennes, 1836) de Pernambuco, Brasil. 260 f. Thesis (Doctoral in Biological Oceanography)- Université de Bretagne Occidentale, França, 2007.

SILVA, I. F. Dados climatológicos de Cananéia e Ubatuba (Estado de São Paulo). Série de 1956-1985. Bol. Climatol., v.6, p.1-21, 1989 .

SOUZA-CONCEIÇÃO, J. M.; SPACH, H. L.; BORDIN, D.; FRISANCO, D.; COSTA, M. D. P. The role of estuarine beaches as habitats for fishes in a Brazilian subtropical environment. Neotrop. Biol. and Cons., v. 8, n. 3, p. 121131,2013

VASCONCELlOS, R. M.; SANTOS, J. N. de S.; SILVA, M. A.; ARAÚJO, F. G. Efeito do grau de exposição às ondas sobre a comunidade de peixes juvenis em praias arenosas do Município do Rio de Janeiro, Brasil. Biota Neotrop., v. 7, n. 1, p. 93-100, 2007. 
VAZZOLER, A. E. A. M. Biologia da reprodução de peixes teleósteos: Teoria e prática. Maringá: Eduem. 1996. 169p.

VIEIRA, J. P. Juvenile Mullets (Pisces: Mugilidae) in the Estuary of Lagoa dos Patos, RS, Brazil. Copeia, v. 2, p. 409-418, 1991.

VIEIRA, J. P.; SCALABRIN, C. Migração reprodutiva da "Tainha" (Mugil platanus GUNTHER, 1980) no sul do Brasil. Atlântica, v. 13, n. 1, p. 131-141, 1991.

WATT- PRINGLE, P.; STRYDOM, N. A. Habitat use by larval fishes in a temperate South African surf zone. Estuar. Coast. Shelf Sci., v. 58, n.4, p. 765-774, 2003.
WENER, R. G. Habitat Requeriments. In: FUIMAN, L. A.; WENER, R. G. (Eds.). Fishery Science: The unique contributions of early life history. United Kingdom: Blackwell Science, 2002. p. 161-182.

WRIGHT, P. J.; TOBIN, D.; GIBB, F. M.; GIBB, I. M. Assessing nursery contribution to recruitment: relevance of closed areas to haddock Melanogrammus aeglefinus. Mar. Ecol. Prog. Ser., v. 400, p. 221-232, 2010.

ZANI-TEIXEIRA, M. L. Contribuição ao conhecimento da ictiofauna da Baía do Trapandé, Complexo Estuarino Lagunar de Cananéia, São Paulo. 254 f. Dissertation (Master in Biological Oceanography)- Instituto Oceanográfico, Universidade de São Paulo, São Paulo, 1983. 